Jurnal Akuntansi Manajemen Madani

Vol. 6, No. 1, Maret 2020

\title{
PENGARUH DISIPLIN KERJA, MOTIVASI DAN GAYA KEPEMIMPINAN \\ TERHADAP KINERJA KARYAWAN BROWNIES AMANDA \\ CABANG BALIKPAPAN
}

\section{Dwi Ayuningtyas Nurul Fathiya Sumantri, Rahajeng Cahyaning Putri Cipto \\ STIE Madani Balikpapan}

\begin{abstract}
This research aims to figure out the influence of the working discipline, motivation and leadership style to the employee's performance of Brownies Amanda Balikpapan Branch. The type of the research is descriptive quantitative and the primary data source is taken from 71 respondents. Based on the results of multiple linear regression test, the working discipline, motivation and leadership style simultaneously influence the employee's performance of 272,249. Partially, motivation variable and leadership style variable have a significant influence on the employee's performance which are 4,206 and 6,794. While working discipline variable has no significant influence on the employee's performance which is 1,289.
\end{abstract}

Keywords: Working Discipline, Motivation, Leadership Style, Employee Performance

\section{PENDAHULUAN}

Perkembangan pada era globalisasi saat ini dunia kerja sangat dituntut untuk menciptakan kinerja karyawan yang tinggi guna pengembangan perusahaan. Perusahaan harus mampu bersaing untuk membangun dan meningkatkan kinerja di dalam lingkungannya. Dalam upaya mencapai keberhasilan suatu perusahaan pasti dipengaruhi oleh beberapa faktor, salah satu faktor penting yang mempengaruhi keberhasilan suatu perusahaan adalah sumber daya manusia, karena sumber daya manusia merupakan subjek atau pelaku dari keseluruhan tingkat mulai dari perencanaan sampai dengan tahap evaluasi. Dalam suatu organisasi tersebut seorang pemimpin memberikan pengaruh yang cukup besar, seorang pemimpin memiliki peran besar dalam mendampingi untuk mewujudkan peningkatan kinerja karyawannya, yaitu dengan persaingan yang ada mampu memberi dan membentuk kondisi kerja yang mengutamakan kepentingan perusahaan dari pada kepentingan pribadi. Kinerja karyawan (prestasi kerja) adalah hasil kerja secara kualitas dan kuantitas yang dicapai oleh seorang karyawan dalam 
melaksanakan tugasnya sesuai dengan tanggung jawab yang diberikan kepadanya (Mangkunegara, 2013: 67).

Brownies Amanda Cabang Balikpapan merupakan organisasi yang bergerak dalam industri makanan. Brownies Amanda Cabang Balikpapan membutuhkan sumber daya manusia yang potensial, baik antara pemimpin maupun karyawan pada pola tugas serta pengawasan yang merupakan penentu tercapainya tujuan perusahaan dan terdapat beberapa faktor yang mempengaruhi kinerja karyawan, seperti disiplin kerja salah satunya. seperti yang terjadi di Brownies Amanda Cabang Balikpapan ialah keterlambatan pada waktu masuk jam kerja, dan izin tanpa keterangan.

Selain itu, fenomena yang terjadi mengenai motivasi terhadap karyawan pada Brownies Amanda cabang Balikpapan ialah kurangnya perhatian atasan seperti memberi motivasi atau nasehat kepada karyawan dan kurangnya motivasi antar sesama karyawan dikarenakan komunikasi yang kurang efektif. Sehingga menyebabkan adanya ketidakdisiplinan karyawan dalam bekerja, hal tersebut dapat dijadikan acuan dalam mengaktifkan motivasi kerja karyawan agar dapat bekerja dengan giat dan agar dapat meningkatkan kinerja karyawannya.

Penyebab kurangnya motivasi tersebut karena gaya kepemimpinan yang kurang baik. Hal tersebut dirasakan karyawan pada pimpinannya, apabila gaya kepemimpinan tersebut kurang maka dapat mengakibatkan turunnya kinerja karyawan yang dapat mempengaruhi disiplin kerja dan motivasi.

Berdasarkan uraian diatas, maka penulis tertarik untuk melakukan penelitian dengan judul penelitian, "Pengaruh Disiplin Kerja, Motivasi dan Gaya Kepemimpinan terhadap Kinerja Karyawan Brownies Amanda cabang Balikpapan”. Adapun rumusan masalah dalam penelitian ini sebagai berikut: (1) Apakah Disiplin Kerja, Motivasi Dan Gaya Kepemimpinan berpengaruh secara Simultan (bersama-sama) terhadap Kinerja Karyawan Brownies Amanda Cabang Balikpapan?, (2) Apakah Disiplin Kerja, Motivasi Dan Gaya Kepemimpinan berpengaruh secara parsial (signifikan) terhadap Kinerja Karyawan Brownies Amanda Cabang Balikpapan? 


\section{KERANGKA TEORI}

\section{Kinerja Karyawan}

Mangkunegara (2010:9) adalah prestasi kerja atau hasil kerja (output) baik kualitas maupun kuantitas yang dicapai SDM persatuan periode waktu dalam melaksanakan tugas kerjanya sesuai dengan tanggung jawab yang diberikan kepadanya.

Penilaian kinerja atau performance appraisal adalah proses dengan mana kinerja individual diukur dan dievaluasi. Penilaian kinerja menjawab pertanyaan, seberapa baik pekerja berkinerja selama periode waktu tertentu (Bacal dalam Wibowo, 2014:187).

Adapun manfaat penilaian kinerja bagi organisasi atau perusahaan dalam Rivai dan Sagala (2010:554) diantaranya :

1. Posisi tawar.

2. Perbaikan Kinerja

3. Penyesuaian kompensasi

4. Keputusan penempatan

5. Pelatihan dan pengembangan

6. Perencanaan dan pengembangan karir

\section{Disiplin Kerja}

Rivai \& Sagala (2010: 825) mengungkapkan bahwa disiplin kerja adalah suatu alat yang digunakan para manajer untuk berkomunikasi dengan karyawan agar mereka bersedia untuk mengubah suatu perilaku serta sebagai suatu upaya untuk meningkatkan kesadaran dan kesediaan seseorang mentaati semua peraturan perusahaan dan norma-norma sosial yang berlaku. Berikut yang termausk dalam macam-macam disiplin kerja:

Rivai dan Sagala (2010: 825) terdapat empat perspektif daftar yang menyangkut disiplin kerja, yaitu :

a. Disiplin Retributif (Retributive Discipline), yaitu berusaha menghukum orang yang berbuat salah.

b. Disiplin Korektif (Corrective Discipline), yaitu berusaha membantu karyawan mengoreksi perilakunya yang tidak tepat. 
c. Perspektif hak-hak individu (Individual Rights Perspective), yaitu berusaha melindungi hak-hak dasar individu selama tindakan-tindakan disipliner.

d. Perspektif Utilitarian (Utilitarian Perspective), yaitu berfokus kepada penggunaan disiplin hanya pada saat konsekuensi-konsekuensi tindakan disiplin melebihi dampak-dampak negatifnya.

\section{Motivasi}

Siagian (2012:138) mengungkapkan motivasi adalah daya pendorong yang mengakibatkan seseorang anggota organisasi mau dan rela untuk mengerahkan kemampuan dalam bentuk keahlian atau keterampilan tenaga dan waktunya untuk menyelenggarakan berbagai kegiatan yang menjadi tanggung jawabnya dan melaksanakan kewajibannya, dalam rangka pencapaian tujuan dan berbagai sasaran organisasi yang telah ditentukan sebelumnya.

Newstrom dalam Wibowo (2013:112) melihat sebagai dorongan motivasi bersumber pada penelitian McClelland yang memfokuskan pada tiga dorongan yaitu :

\section{Achievment motivation}

Motivasi berprestasi adalah salah satu dorongan yang dimiliki banyak orang untuk mengejar dan mencapai tujuan menantang. Individu dengan dorongan ini mengharapkan mencapai sasaran dan menaiki tangga keberhasilan.

2. Afiliation motivation

Motivasi untuk berafiliasi merupakan suatu dorongan untuk berhubungan dengan orang atas dasar sosial, bekerja dengan orang yang cocok dan berpengalaman dengan perasaan sebagai komunitas.

\section{Power motivation}

Motivasi akan kekuasaan merupakan suatu dorongan untuk memengaruhi orang, melakukan pengawasan dan mengubah situasi orang yang termotivasi atas dasar kekuasaan mengharapkan menciptakan dampak pada organisasi dan bersedia mengambil risiko dengan melakukannya.

\section{Gaya Kepemimpinan}

Wirawan (2014:352) berpendapat bahwa gaya kepemimpinan adalah sebagai pola perilaku pemimpin dalam mempengaruhi sikap, perilaku dan sebagainya para pengikutnya.. Macam-macam Gaya Kepemimpinan dalam Rivai (2012): 


\section{Gaya Kepemimpinan Otoriter/Authoritarian}

Gaya pemimpin yang memusatkan segala keputusan dan kebijakan yang diambil dari dirinya sendiri secara penuh. Segala pembagian tugas dan tanggung jawab dipegang oleh si pemimpin yang otoriter tersebut, sedangkan para bawahan hanya melaksanakan tugas yang telah diberikan.

2. Gaya Kepemimpinan Demokratis/Democratic

Gaya Kepemimpinan demokratis adalah gaya pemimpin yang memberikan wewenang secara luas kepada para bawahan. Setiap ada permasalahan selalu mengikutsertakan bawahan sebagai suatu tim yang utuh. Dalam gaya kepemimpinan demokratis pemimpinan memberikan banyak informasi tentang tugas serta tanggung jawab para bawahannya.

3. Gaya Kepemimpinan Bebas/Laissez Faire

Pemimpin jenis ini hanya terlibat dalam kuantitas yang kecil di mana para bawahannya yang secara aktif menentukan tujuan dan penyelesaian masalah yang dihadapi. Terdapat empat macam gaya kepemimpinan berdasarkan kepribadian. Keempat gaya kepemimpnan berdasarkan kepribadian yaitu adalah:
a) Gaya Kepemimpinan Karismatik
b) Gaya Kepemimpinan Diplomatis
c) Gaya Kepemimpinan Otoriter
d) Gaya Kepemimpinan Moralis

\section{METODE PENELITIAN}

\section{Jenis Penelitian}

Umar (2010:4) menjelaskan bahwa data dalam penelitian kualitatif berbentuk kata-kata, gambar dan sedikit angka yang dianalisis dalam terminologi respons-respons individual, kesimpulan deskriptif atau keduanya. Karena sifatnya, maka untuk dapat diolah menjadi informasi yang berguna. Data jenis ini harus diubah dahulu menjadi data kuantitatif atau dikuantitatifkan untuk dapat diproses, mengingat statistik hanya dapat memproses data yang berupa angka (Wibowo, 2012:3). Hal ini dilakukan untuk mengetahui nilai masing-masing variabel yaitu variabel disiplin kerja, motivasi dan gaya kepemimpinan terhadap kinerja 
karyawan. Serta, sejauh mana hubungan yang terjadi antara variabel terikat dan variabel bebas tersebut berpengaruh.

\section{Sumber Data}

Sumber data yang digunakan dalam penelitian ini adalah data primer, yaitu data yang didapat dari sumber pertama baik dari individu atau perorangan seperti hasil wawancara atau hasil pengisian kuesioner yang biasa dilakukan oleh peneliti, (Umar, 2013:42). Dalam penelitian ini penulis mengumpulkan data primer yang diperoleh melalui kuesioner yang dibagikan kepada karyawan Brownies Amanda Cabang Balikpapan.

\section{Teknik Pengumpulan Data}

Umar (2013:49) berpendapat bahwa angket atau kuesioner merupakan suatu pengumpulan data dengan memberikan atau menyebarkan daftar pertanyaan/pernyataan kepada responden dengan harapan memberikan respons atas daftar pertanyaan tersebut. Daftar pertanyaan/pernyataan dapat bersifat terbuka jika jawaban tidak ditentukan sebelumnya sedangkan bersifat tertutup jika alternatif-alternatif jawaban telah disediakan. Dalam penelitian ini, metode pengumpulan data yang digunakan yakni penggunaan jenis kuesioner dengan skala likert yaitu sebuah pernyataan diikuti kolom-kolom yang menunjukkan tingkatan-tingkatan, misalnya dari sangat tidak setuju hingga sangat setuju. Hasil dari pengumpulan data melalui teknik kuesioner akan menjadi acuan data yang akan disajikan dalam bentuk angka-angka kemudian diinterprestasikan dalam suatu uraian.

\section{Populasi dan Sampel}

Sugiyono (2009:80) mengemukakan bahwa populasi adalah wilayah generalisasi yang terdiri atas obyek atau subyek yang mempunyai kualitas dan karakteristik tertentu yang ditetapkan oleh peneliti untuk dipelajari dan kemudian ditarik kesimpulannya. Populasi dalam penelitian ini adalah sebanyak 71 orang yang terdiri dari bagian produksi, kordinator lapangan, kordinator divisi, dan anggota Brownies Amanda Cabang Balikpapan.

Sampel adalah bagian dari jumlah dan karakteristik yang dimiliki oleh populasi tersebut. Mengingat jumlah populasi yang tidak terlalu banyak, Sugiyono (2009:81). Maka teknik 
pengambilan sampel yang digunakan yaitu dengan menggunakan teknik sampling berupa sampling jenuh pada penelitian ini yaitu 71 orang. Berdasarkan pendapat Sugiyono (2015:85) sampling jenuh merupakan teknik penentuan sampel bila semua anggota populasi digunakan sebagai sampel. Hal ini dilakukan bila jumlah populasi relatif kecil,

\section{METODE ANALISIS}

\section{Uji Validitas dan Uji Reliabilitas}

Priyatno (2014:51) mendefinisikan Uji validitas item merupakan uji instrument data untuk mengetahui seberapa cermat suatu item dalam mengukur apa yang ingin diukur. Item dapat dikatakan valid jika adanya korelasi yang signifikan dengan skor totalnya, hal ini menunjukkan adanya dukungan item tersebut dalam mengungkap suatu yang ingin diungkap. Item biasanya berupa pertanyaan atau pernyataan yang ditujukan kepada responden dengan menggunakan bentuk kuesioner dengan tujuan untuk mengungkap sesuatu.

Uji validitas dapat digunakan dengan cara mengkorelasikan skor item dengan skor totalnya. Pengujian signifikan dilakukan dengan kriteria menggunakan $r$ tabel pada tingkat signifikansi 0,05 dengan uji 2sisi. Jika nilai positif dan $r$ hitung $>r$ tabel maka item dapat dinyatakan valid, jika $\mathrm{r}$ hitung < tabel maka item dinyatakan tidak valid.

Priyatno (2014: 64) mendefinisikan Uji reliabilitas digunakan untuk mengetahui keajegan atau konsistensi alat ukur yang biasanya menggunakan kuesioner. Metode yang sering digunakan dalam penelitian untuk mengukur skala rentangan (seperti skala Likert 1-5) adalah Cronbach Alpha. Untuk menentukan apakah instrumen reliabel atau tidak menggunakan batasan 0,6. Menurut Sekaran (1992), reliabilitas kurang dari 0,6 adalah kurang baik, sedangkan 0,7 dapat diterima dan di atas 0,8 adalah baik. Uji reliabilitas dalam penelitian ini dilakukan dengan software SPSS 21.

\section{Uji Asumsi Klasik}

Uji asumsi klasik merupakan prasyarat analisis regresi berganda. Sebelum melakukan pengujian hipotesis, maka yang diajukan dalam penelitian adalah melakukan pengajuan asumsi klasik meliputi Uji Normalitas, Uji Multikolinieritas, Uji heteroskedastisitas, dan Uji Autokorelasi.

1. Uji Normalitas 
Ghozali (2013:160) berpendapat bahwa uji normalitas bertujuan untuk menguji apakah dalam model regresi nilai residual yang dihasilkan dari regresi terdistribusi secara normal atau tidak. Model regresi yang baik adalah yang memiliki nilai residual yang berdistribusi secara normal. Beberapa metode uji normalitas pada sumber diagonal pada grafik normal PP-Plot of Regression Strandarized Residual atau dengan uji One Sample KolmogorovSmirnov.

2. Uji Multikolinieritas

Uji multikolinieritas bertujuan untuk menguji apakah model regresi ditemukan adanya korelasi antar variabel bebas (independen). Model regresi yang baik seharusnya tidak terjadi korelasi diantara variabel independen. Jika variabel independen saling berkorelasi, maka variabel-variabel ini tidak orthogonal. Variabel ortogonal adalah variabel independen yang nilai korelasi antar sesama variabel independen sama dengan nol. Untuk mendeteksi ada atau tidaknya multikolinieritas di dalam model regresi adalah sebagai berikut: (Ghozali, 2013:105).

3. Uji Heteroskedastisitas

Uji Heteroskedastisitas bertujuan menguji apakah dalam model regresi terjadi ketidaksamaan variance dari residual data pengamatan ke pengamatan lain tetap, maka disebut heteroskedastisitas. Model regresi yang baik adalah yang homoskedastisitas atau tidak terjadi heteroskedastisitas.

4. Uji Autokorelasi

Uji autokorelasi bertujuan menguji apakah dalam model regresi linier ada korelasi antara kesalahan pengganggu pada periode t-1 (sebelumnya). Jika terjadi korelasi, maka dinamakan ada problem autokorelasi. Autokorelasi muncul karena observasi yang berurutan sepanjang waktu berkaitan satu sama lainnya. Ghozali (2013:111) untuk mendeteksi ada atau tidaknya autokorelasi dapat dilakukan dengan uji Durbin Watson (DW) dengan ketentuan sebagai berikut:

1. $0<\mathrm{d}<\mathrm{dl}$, artinya Tidak ada autokorelasi positif.

2. $\mathrm{dl} \leq \mathrm{d} \leq \mathrm{du}$, artinya Tidak ada autokorelasi positif.

3. $4-\mathrm{dl}<\mathrm{d}<4$, artinya Tidak ada korelasi negative. 
4. $4-\mathrm{du} \leq \mathrm{d} \leq 4-\mathrm{dl}$, artinya Tidak ada korelasi negative.

5. $\mathrm{du}<\mathrm{d}<4-\mathrm{du}$, artinya Tidak ada autokorelasi Positif atau Negative.

\section{Analisis Regresi Berganda}

Sugiyono (2013:277) mengemukakan Analisis regresi ganda digunakan oleh peneliti, bila peneliti bermaksud meramalkan bagaimana keadaan (naik turunnya) variabel dependen (kriterium), bila dua faktor atau lebih variabel sebagai faktor predictor dimanipulasi (dinaik turunkan nilainnya). Jadi analisis regresi ganda akan dilakukan bila jumlah variabel independennya minimal 2. Secara umum data hasil pengamatan Y dipengaruhi oleh variabelvariabel bebas $\mathrm{X} 1, \mathrm{X} 2, \mathrm{X} 3, \mathrm{Xn}$ sehingga rumus dari model regresi berganda dalam penelitian ini sebagai berikut:

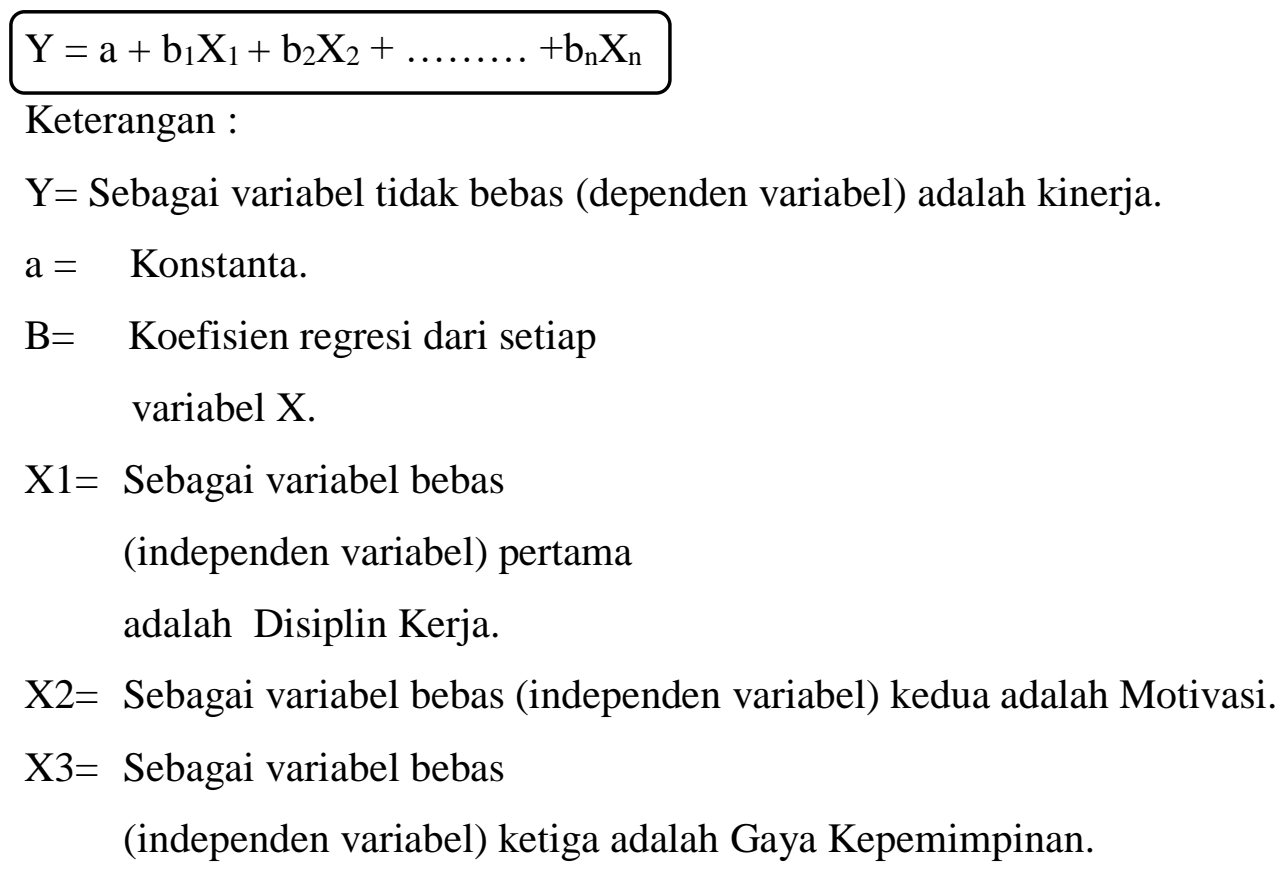

\section{Koefisien Korelasi}

Analisis korelasi bertujuan untuk mengukur kekuatan asosiasi (hubungan) linier antara dua variabel. Korelasi tidak menunjukkan hubungan fungsional atau dengan kata lain analisis korelasi tidak membedakan antara variabel dependen dengan variabel independen. Pedoman untuk memberikan interpretasi korelasi adalah (Sugiyono, 2013:250): 


\section{Koefisien Determinan $\left(\mathbf{R}^{2}\right)$}

Ghozali (2013:97) mendefinisikan bahwa koefisien determinan $\left(\mathrm{R}^{2}\right)$ pada intinya mengukur seberapa jauh kemampuan model dalam menerangkan variasi variabel dependen. Nilai koefisien determinan adalah antara nol dan satu. Nilai $\mathrm{R}^{2}$ yang kecil berarti kemampuan variabel-variabel independen dalam menjelaskan variabel-variabel dependen amat terbatas. Nilai yang mendekati satu berarti variabel-variabel independen memberikan hampir semua informasi yang dibutuhkan untuk memprediksi variasi variabel dependen.

Kelemahan mendasar penggunaan koefisisen determinan adalah bias terhadap jumlah variabel independen yang dimasukkan kedalam model. Setiap tambahan satu variabel independen, maka $\mathrm{R}^{2}$ pasti meningkat tidak peduli apakah variabel tersebut berpengaruh secara signifikan terhadap variabel dependen. Oleh Karena itu banyak peneliti menganjurkan untuk menggunakan nilai Adjusted $\mathrm{R}^{2}$, nilai Adjusted $\mathrm{R}^{2}$ dapat naik atau turun apabila satu variabel independen ditambah kedalam model. Ghozali (2013:97) menjelaskan bahwa jika dalam uji empiris didapat nilai Adjusted $\mathrm{R}^{2}$ negatif, maka nilai adjusted $\mathrm{R}^{2}$ dianggap bernilai nol. Secara sistematis jika nilai $R^{2}=1$, maka adjusted $R^{2}=1$ sedangkan jika nilai $R^{2}=0$, maka abjusted $R^{2}$ akan bernilai negative.

\section{Pengujian Hipotesis}

\section{A. Uji Simultan (Uji F)}

Ghozali (2013:98) mengemukakan bahwa Uji F pada dasarnya menunjukan apakah semua variabel independen atau bebas yang dimasukkan dalam model mempunyai pengaruh secara bersama-sama terhadap variabel dependen/terikat. Dari uji $\mathrm{F}$ dapat disimpulkan sebagai berikut :

1. Apabila $\mathrm{F}_{\text {hitung }}<\mathrm{F}_{\text {tabel }} \mathrm{H}_{\mathrm{o}}$ diterima dan $\mathrm{H}_{\mathrm{a}}$ ditolak, ini berarti bahwa secara bersamasama disiplin kerja, motivasi, gaya kepemimpinan tidak berpengaruh terhadap kinerja karyawan Brownies Amanda Cabang Balikpapan.

2. Apabila $\mathrm{F}_{\text {hitung }}>\mathrm{F}_{\text {tabel }} \mathrm{H}_{\mathrm{o}}$ ditolak dan $\mathrm{H}_{\mathrm{a}}$ diterima, ini berati bahwa secara bersamasama disiplin kerja, motivasi, gaya kepemimpinan berpengaruh terhadap kinerja karyawan Brownies Amanda Cabang Balikpapan.

B. Uji Parsial (Uji t) 
Uji ini pada dasarnya menunjukan seberapa jauh pengaruh satu variabel penjelas/independen secara individual dalam menerangkan variabel-variabel dependen (Ghozali, 2013:98). Uji $t$ ini dilakukan dengan cara menghitung nilai $t_{\text {hitung }}$ dan nilai $t_{\text {tabel. }}$ Hipotesis akan diterima atau ditolak ditentukan sebagai berikut :

1. Apabila thitung $<t_{\text {tabel }}$ maka $H_{o}$ diterima $H_{a}$ ditolak, ini berarti bahwa secara parsial disiplin kerja, motivasi, gaya kepemimpinan tidak berpengaruh terhadap kinerja karyawan Brownies Amanda Cabang Balikpapan.

2. Apabila $t_{\text {hitung }}>\mathrm{t}_{\text {tabel }}$ maka $\mathrm{H}_{\mathrm{o}}$ ditolak $\mathrm{H}_{\mathrm{a}}$ diterima, ini berarti secara parsial disiplin kerja, motivasi, gaya kepemimpinan berpengaruh terhadap kinerja karyawan Brownies Amanda Cabang Balikpapan.

\section{HASIL PENELITIAN DAN PEMBAHASAN}

\section{Uji Validitas}

Uji validitas digunakan untuk mengukur valid tidaknya suatu kuesioner. Uji ini dilakukan dengan cara membandingkan hasil $r$ hitung dengan $r$ tabel. Dalam penelitian ini nilai r tabel sebesar 0,234 yang diperoleh dari nilai df (n-2), yaitu $71-2=69$. Apabila nilai $r$ hitung suatu item pernyataan besarnya lebih dari 0,234 maka item tersebut dinyatakan valid. Berikut hasil perhitungan uji validitas untuk masing-masing variabel dengan menggunakan program SPSS 21.0 for Windows.

Tabel 1. Hasil Uji Validitas

\begin{tabular}{|c|c|c|c|c|c|}
\hline \multirow{2}{*}{ No } & Variabel & Item & $\begin{array}{c}\mathbf{R} \\
\text { Hitung }\end{array}$ & $\begin{array}{c}\mathbf{R} \\
\text { Tabel }\end{array}$ & Keterangan \\
\hline \multirow{2}{*}{1} & Disiplin Kerja & $\mathrm{X} 1 \_1$ & 0,923 & 0,234 & Valid \\
\cline { 3 - 6 } & $\left(\mathrm{X}_{1}\right)$ & $\mathrm{X} 1 \_2$ & 0,923 & 0,234 & Valid \\
\cline { 3 - 6 } & & $\mathrm{X} 1 \_3$ & 0,489 & 0,234 & Valid \\
\cline { 3 - 6 } & & $\mathrm{X} 1 \_4$ & 0,923 & 0,234 & Valid \\
\cline { 3 - 6 } & & $\mathrm{X} 1 \_5$ & 0,519 & 0,234 & Valid \\
\hline 2 & Motivasi & $\mathrm{X} 2 \_1$ & 0,966 & 0,234 & Valid \\
\hline
\end{tabular}




\begin{tabular}{|c|c|c|c|c|c|}
\hline & \multirow[t]{4}{*}{$\left(\mathrm{X}_{2}\right)$} & X2_2 & 0,966 & 0,234 & Valid \\
\hline & & $\mathrm{X} 2 \_3$ & 0,966 & 0,234 & Valid \\
\hline & & X2_4 & 0,279 & 0,234 & Valid \\
\hline & & X2_5 & 0,966 & 0,234 & Valid \\
\hline \multirow[t]{5}{*}{3} & \multirow{5}{*}{$\begin{array}{c}\text { Gaya } \\
\text { Kepemimpinan } \\
\left(\mathrm{X}_{3}\right)\end{array}$} & X3_1 & 0,251 & 0,234 & Valid \\
\hline & & X3_2 & 0,851 & 0,234 & Valid \\
\hline & & X3_3 & 0,940 & 0,234 & Valid \\
\hline & & X3_4 & 0,508 & 0,234 & Valid \\
\hline & & X3_5 & 0,948 & 0,234 & Valid \\
\hline \multirow[t]{5}{*}{4} & \multirow{5}{*}{$\begin{array}{l}\text { Kinerja } \\
(\mathrm{Y})\end{array}$} & Y1 & 0,964 & 0,234 & Valid \\
\hline & & Y2 & 0,964 & 0,234 & Valid \\
\hline & & Y3 & 0,321 & 0,234 & Valid \\
\hline & & Y4 & 0,964 & 0,234 & Valid \\
\hline & & Y5 & 0,379 & 0,234 & Valid \\
\hline
\end{tabular}

Sumber : Hasil Olah Uji SPSS 21.0

\section{Uji Reliabilitas}

Uji reliabilitas digunakan untuk menunjukkan stabil atau tidaknya alat ukur yang digunakan atau sejauh mana konsistensi alat ukur tersebut. Hasil uji reliabilitas dinyatakan reliabel apabila hasil perhitungan memiliki koefisien keandalan sebesar $\alpha>0,60$. Berikut hasil pengujian reliabilitas :

Tabel 2.

Hasil Uji Reliabilitas

\begin{tabular}{|c|c|c|c|}
\hline No & $\begin{array}{c}\text { Variabel Independen dan } \\
\text { Dependen }\end{array}$ & Cronbach's Alpha & Keterangan \\
\hline 1. & Disiplin Kerja $\left(\mathrm{X}_{1}\right)$ & 0,839 & Reliabel \\
\hline 2. & Motivasi $\left(\mathrm{X}_{2}\right)$ & 0,877 & Reliabel \\
\hline 3. & Gaya Kepemimpinan $\left(\mathrm{X}_{3}\right)$ & 0,789 & Reliabel \\
\hline 4. & Kinerja (Y) & 0,829 & Reliabel \\
\hline
\end{tabular}

Sumber : Hasil Olah Uji SPSS 21.0 
Hasil pengujian reliabilitas pada tabel 4.10. dapat disimpulkan bahwa variabel Disiplin Kerja $\left(\mathrm{X}_{1}\right)$, Motivasi $\left(\mathrm{X}_{2}\right)$, Gaya Kepemimpinan $\left(\mathrm{X}_{3}\right)$, dan Kinerja Karyawan $(\mathrm{Y})$ menunjukkan nilai koefisien Alpha lebih besar dari 0,60. Sehingga seluruh variabel dalam penelitian dinyatakan reliabel dan dapat digunakan sebagai alat pengumpul data.

\section{Uji Asumsi Klasik}

\section{Uji Normalitas}

\section{Gambar 1.}

\section{Hasil Uji Normalitas Variabel Disiplin Kerja}

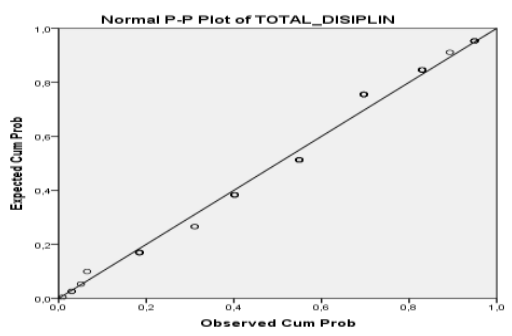

Sumber : Hasil Olah Uji SPSS 21.0

Gambar 2.

Hasil Uji Normalitas Variabel Motivasi

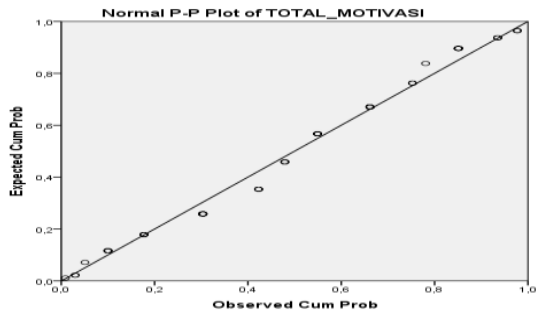

Sumber : Hasil Olah Uji SPSS 21.0

Gambar 3.

Hasil Uji Normalitas Variabel (Gaya Kepemimpinan)

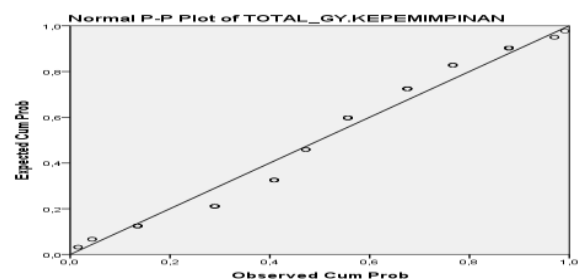

Sumber : Hasil Olah Uji SPSS 21.0

Gambar 4. Hasil Uji Normalitas

Variabel Kinerja 


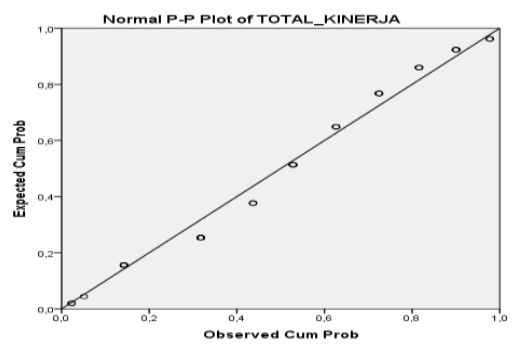

Berdasarkan tabel 3. diatas dapat diketahui nilai Asymp Sig. (2 tailed) adalah sebesar 0,981 melebihi batas signifikan 0,05 atau 5\% sehingga dapat disimpulkan data berdistribusi normal.

\section{Uji Multikolinearitas}

Tabel 4.

Hasil Uji Multikolinearitas

\begin{tabular}{|c|c|c|}
\hline & \multicolumn{2}{|c|}{ Coefficients $^{a}$} \\
\hline \multirow[t]{2}{*}{ Model } & \multicolumn{2}{|c|}{ Collinearity Statistics } \\
\hline & Tolerance & VIF \\
\hline $\begin{array}{l}\text { (Constant) } \\
\text { TOTAL_DISIPLIN } \\
\text { TOTAL_MOTIVAS } \\
\text { TOTAL_G.KEPEMI } \\
\text { MPINAN }\end{array}$ & $\begin{array}{rr} & , 180 \\
& , 150 \\
& , 188 \\
& \end{array}$ & $\begin{array}{r}5,565 \\
6,678 \\
5,322\end{array}$ \\
\hline
\end{tabular}

a. Dependent Variable: TOTAL_KINERJA

Sumber : Hasil Olah Uji SPSS 21.0

Berdasarkan tabel 4. di atas menunjukkan hasil uji pada variabel Disiplin Kerja menghasilkan angka tolerance sebesar 0,180 dan nilai VIF 5,565. Variabel Motivasi memiliki nilai tolerance sebesar 0,150 dan nilai VIF sebesar 6,678. Dan yang terakhir variabel Gaya Kepemimpinan menunjukkan nilai masing-masing sebesar 0,188 dan 5,322. Berdasarkan nilai dari Variance Inflation Factor (VIF) yang menunjukkan bahwa ketiga variabel independen tersebut, yaitu Disiplin Kerja, Motivasi, Dan Gaya Kepemimpinan memiliki nilai VIF $\leq 10$ (kurang dari 10) atau 10\% dan nilai tolerance lebih dari 0,10, maka dapat ditarik kesimpulan bahwa model regresi di atas tidak terjadi multikolinearitas. 


\title{
Uji Heteroskedastisitas
}

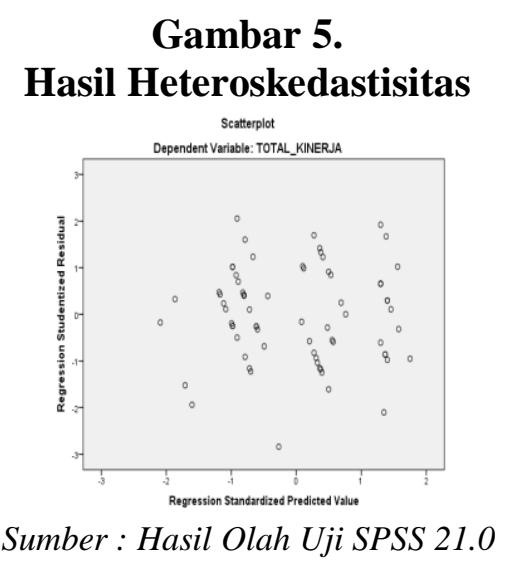

\section{Uji Autokorelasi}

\author{
Hasil Uji Autokorelasi Uji Durbin Watson \\ Model Summary

\begin{tabular}{|c|c|c|c|c|}
\hline $\mathrm{R}$ & $\mathrm{R}$ Square & $\begin{array}{c}\text { Adjusted } \mathrm{R} \\
\text { Square }\end{array}$ & $\begin{array}{c}\text { Std. Error of } \\
\text { the Estimate }\end{array}$ & Durbin-Watson \\
\hline, $961^{\mathrm{a}}$ &, 924 &, 921 &, 808 & 2,135 \\
\hline
\end{tabular} \\ TOTAL_DISIPLIN, TOTAL_MOTIVASI \\ b. Dependent Variable: TOTAL_KINERJA
}

Berdasarkan tabel 4.14. dapat dilihat bahwa angka/ nilai Durbin Watson (DW) sebesar 2,135 dengan nilai (dL) sebesar 1,528 dan nilai (dU) sebesar 1,704, sehingga dapat dihitung sebagai berikut :

$=\mathrm{du}<\mathrm{d}<4-\mathrm{du}=1,704<2,135<4-1,704$. Maka dapat disimpulkan bahwa dalam penelitian ini tidak terjadi autokorelasi positif ataupun negative. 


\section{Analisis Regresi Linier Berganda}

\section{Hasil Analisis Regresi Linear \\ Berganda}

\begin{tabular}{|c|c|c|c|c|c|}
\hline \multicolumn{6}{|c|}{ Coefficients $^{a}$} \\
\hline & \multirow[t]{2}{*}{ Model } & \multicolumn{2}{|c|}{$\begin{array}{l}\text { Unstandardized } \\
\text { Coefficients }\end{array}$} & \multirow[t]{2}{*}{$t$} & \multirow[t]{2}{*}{ Sig. } \\
\hline & & $B$ & Std. Error & & \\
\hline \multirow{4}{*}{1} & (Constant) & 2,519 & ,751 & 3,354 & 001 \\
\hline & $\underset{\text { IN }}{\text { TOTALISIPL }}$ & 097 & 075 & 1,289 & ,202 \\
\hline & $\begin{array}{c}\text { TOTAL_MOTIV } \\
\text { ASI }\end{array}$ & 286 & ,068 & 4,206 & ,000 \\
\hline & $\begin{array}{l}\text { TOTAL_GY.KE } \\
\text { PEMIMPINAN }\end{array}$ &, 529 & 078 & 6,794 &, 000 \\
\hline
\end{tabular}

a. Dependent Variable: TOTAL_KINERJA

Berdasarkan tabel 7. maka dapat dijelaskan ke dalam persamaan fungsi analisis regresi linear berganda, yaitu sebagai berikut :

$\mathbf{Y}=\mathbf{a}+\mathbf{b}_{1} \mathbf{X}_{1}+\mathbf{b}_{2} \mathbf{X}_{2}+\mathbf{b}_{3} \mathbf{X}_{3}$

$Y=2,519+0,097 X_{1}+0,286 X_{2}+0,529 X_{3}$

Bunyi interprestasi dari persamaan fungsi analisis regresi linear berganda di atas dapat diperoleh melalui penjelasan secara rinci berikut:

1. Nilai konstanta sebesar 2,519 , artinya ketika variabel disiplin kerja $\left(\mathrm{X}_{1}\right)$, motivasi $\left(\mathrm{X}_{2}\right)$, dan gaya kepemimpinan $\left(\mathrm{X}_{3}\right)$ dianggap konstan dan tidak ada perubahan, maka besarnya efektivitas kinerja (Y) adalah sebesar 2,519.

2. Variabel disiplin kerja $\left(X_{1}\right)$ mempunyai nilai koefisien sebesar 0,097 , yang memiliki arti bahwa setiap peningkatan 1 satuan variabel disiplin kerja $\left(\mathrm{X}_{1}\right)$, mengakibatkan efektivitas kinerja karyawan (Y) akan meningkat/naik sebesar 0,097 dengan asumsi bahwa variabel bebas yang lain tidak berubah atau konstan.

3. Variabel motivasi $\left(\mathrm{X}_{2}\right)$ mempunyai nilai koefisien sebesar 0,286 , yang artinya bahwa apabila terjadi peningkatan 1 satuan variabel motivasi $\left(\mathrm{X}_{2}\right)$, mengakibatkan efektivitas kinerja karyawan (Y) akan meningkatkan/naik sebesar 0,286 dengan asumsi bahwa variabel bebas yang lain tidak berubah atau konstan.

4. Variabel gaya kepemimpinan $\left(X_{3}\right)$ mempunyai nilai koefisien sebesar 0,529 , yang artinya bahwa apabila terjadi peningkatan 1 satuan variabel gaya kepemimpinan $\left(X_{3}\right)$, 
mengakibatkan variabel kinerja karyawan (Y) akan meningkat sebesar 0,529 dengan asumsi bahwa variabel bebas yang lain tidak berubah atau konstan.

\section{Uji Koefisien Korelasi}

Tabel 8.

Hasil Uji Koefisien Korelasi (R) dan Determinasi $\left(\mathrm{R}^{2}\right)$

\begin{tabular}{|c|c|c|c|}
\hline \multicolumn{4}{|c|}{ Model Summaryb } \\
\hline $\mathrm{R}$ & R Square & $\begin{array}{c}\text { Adjusted R } \\
\text { Square }\end{array}$ & $\begin{array}{c}\text { Std. Error of the } \\
\text { Estimate }\end{array}$ \\
\hline, $961^{\mathrm{a}}$ & 924 & 921 & 808 \\
\hline \multicolumn{4}{|c|}{ a. Predictors: (Constant), TOTAL_GY.KEPEMIMPINAN, } \\
\hline \multicolumn{4}{|c|}{ TOTAL_DISIPLIN, TOTAL_MOTIVASI } \\
\hline
\end{tabular}

Tabel 8. menunjukkan bahwa nilai koefisien korelasi (R) sebesar 0,961. Apabila dilihat dari nilai interval koefisien korelasi tingkat 0,80 - 1,000, maka dapat disimpulkan bahwa terdapat hubungan tingkat korelasi yang sangat kuat antara variabel disiplin kerja $\left(\mathrm{X}_{1}\right)$, motivasi $\left(\mathrm{X}_{2}\right)$, dan gaya kepemimpinan $\left(\mathrm{X}_{3}\right)$ terhadap variabel kinerja $(\mathrm{Y})$ yaitu sebesar $96,1 \%$.

Berdasarkan tabel 8., diperoleh nilai Adjusted $R$ Square atau koefisien determinasi sebesar 0,921. Hal ini berarti bahwa variabel bebas dalam penelitian ini, yaitu disiplin kerja $\left(\mathrm{X}_{1}\right)$, motivasi $\left(X_{2}\right)$, dan gaya kepemimpinan $\left(X_{3}\right)$ memiliki pengaruh sebesar $92,1 \%$ terhadap kinerja (Y) dan sisanya 7,9\% dipengaruhi oleh faktor lain di luar penelitian ini.

\section{PENGUJIAN HIPOTESIS Uji F (Uji Simultan)}

Tabel 9.

Hasil Uji F

\begin{tabular}{|c|c|}
\hline $\mathrm{F}$ & Sig. \\
\hline 272,249 &, $000^{\mathrm{b}}$ \\
\hline
\end{tabular}

Menyatakan hasil perhitungan dan analisa data Uji F diketahui bahwa nilai $F_{\text {hitung }}>F_{\text {tabel }}$ $(272,249>2,741)$ dan nilai signifikan yang diperoleh sebesar $0,00<0,05$, maka Ho ditolak dan Ha diterima dan dapat disimpulkan bahwa terdapat pengaruh secara simultan dan signifikan 
antara variabel independen/bebas, yaitu disiplin kerja $\left(X_{1}\right)$, motivasi $\left(X_{2}\right)$, dan gaya kepemimpinan $\left(\mathrm{X}_{3}\right)$ terhadap variable dependen/terikat, yaitu kinerja karyawan $(\mathrm{Y})$.

\section{Uji T (Uji Parsial)}

Tabel 10.

Hasil Uji t

\begin{tabular}{|c|c|c|}
\hline \multicolumn{3}{|c|}{ Coefficients $^{a}$} \\
\hline Model & $\bar{T}$ & Sig. \\
\hline (Constant) & 3,354 & $\overline{0,01}$ \\
\hline TOTAL_DISIPLIN & 1,289 & 202 \\
\hline TOTAL_MOTIVASI & 4,206 & ,000 \\
\hline & 6,794 & ,000 \\
\hline
\end{tabular}

Berdasarkan hasil perhitungan dan analisis data sebagaimana tabel di atas, maka diperoleh $t_{\text {hitung }}$ sebesar 1,289 dengan nilai sig. sebesar 0,202. Dengan demikian Ho diterima karena thitung $<\mathrm{t}_{\text {tabel }}(1,289<1,996)$ dan nilai sig 0,202 > 0,05 sehingga dinyatakan bahwa secara parsial variabel disiplin kerja $\left(\mathrm{X}_{1}\right)$ tidak terdapat pengaruh yang signifikan terhadap variabel kinerja karyawan Brownies Amanda Cabang Balikpapan.

Berdasarkan hasil perhitungan dan analisis data sebagaimana tabel di atas, maka diperoleh $t_{\text {hitung }}$ sebesar 4,206 dengan nilai sig. sebesar 0,000. Sehingga nilai $t_{\text {hitung }}>t_{\text {tabel }}(4,206>1,996)$ dan nilai sig. 0,000 < 0,05 maka Ho ditolak dan Ha diterima sehingga dinyatakan bahwa secara parsial variabel motivasi $\left(\mathrm{X}_{2}\right)$ terdapat pengaruh yang signifikan terhadap variabel kinerja pada kinerja karyawan Brownies Amanda Cabang Balikpapan.

Berdasarkan hasil perhitungan dan analisis data sebagaimana tabel diatas, maka diperoleh

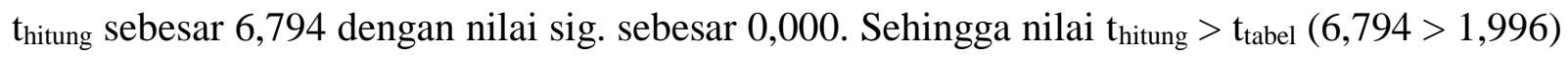
dan nilai sig. 0,000<0,05. maka Ho ditolak dan Ha diterima sehingga dinyatakan bahwa secara parsial variabel gaya kepemimpinan $\left(\mathrm{X}_{3}\right)$ terdapat pengaruh yang signifikan terhadap variabel kinerja pada kinerja karyawan Brownies Amanda Cabang Balikpapan. 


\section{PEMBAHASAN}

\section{Pengaruh Disiplin Kerja, Motivasi, Gaya Kepemimpinan Terhadap Kinerja Karyawan}

Hasil pengujian hipotesis secara simultan (Uji F) telah dilakukan dan menghasilkan nilai perhitungan statistik yang menunjukkan bahwa nilai $F_{\text {hitung }}=272,249>F_{\text {tabel }}=2,741$ maka dapat disimpulkan bahwa Ho ditolak dan Ha diterima yang artinya ada pengaruh antara disiplin kerja, motivasi dan gaya kepemimpinan (bersama-sama) terhadap kinerja karyawan Brownies Amanda Cabang Balikpapan.

\section{Pengaruh Disiplin Kerja Terhadap Kinerja Karyawan}

Dari hasil pengujian, variabel disiplin kerja menunjukkan tidak berpengaruh signifikan terhadap kinerja karyawan Brownies Amanda Cabang Balikpapan. Hal ini terbukti dengan nilai $t_{\text {hitung }}(1,289)<t_{\text {tabel }}(1,996)$ dan nilai sig. 0,202 > 0,05. hasil penelitian ini bertolak belakang dengan penelitian yang dilakukan Ivonne A.S Sajangbati (2013) yang menyatakan bahwa disiplin kerja berpengaruh signifikan terhadap kinerja.

Hal ini bisa terjadi karena dari gaya kepemimpinan yang kurang tegas, sehingga karyawan kurang memperhatikan kedisiplinan, meskipun dalam perhitungan dan pembahasan yang telah dilakukan untuk variabel disiplin kerja tidak mempengaruhi dalam kinerja karyawan

Brownies Amanda Cabang Balikpapan, namun Brownies Amanda Cabang Balikpapan sering mendapat perhatian untuk pengaruh disiplin karyawan dalam kinerja. Karena hal ini dapat ditingkatkan dengan cara pimpinan menuntut dan menanamkan sikap disiplin yang sangat kuat terhadap karyawan Brownies Amanda dalam melaksanakan pekerjaannya dan mengikuti aturan perusahaan serta norma-norma yang diberikan kepada para karyawan tersebut.

Dimana karyawan Brownies Amanda harus bertanggung jawab dalam menggunakan dan memelihara fasilitas kerja dengan prosedur yang telah ditentukan karena tidak semua karyawan sadar akan dengan kedisiplinan perusahaan. Namun kedisiplinan ini memang telah ada dan menjadi kewajiban tiap karyawan sehingga setiap karyawan harus menaati kedisiplinan, mengerjakan pekerjaan sesuai dengan rencana dan tepat waktu dalam penyelesaian pekerjaan, mengevaluasi pekerjaan dan berani bertanggung jawab menerima resiko kesalahan yang dilakukan oleh karyawan tersebut. Sehingga, apabila karyawan menaati semua peraturan yang 
berlaku maka tujuan dan rencana perusahaan dapat terlaksana dan terwujud dengan baik dan mendapatkan hasil sesuai dengan yang diharapkan perusahaan.

\section{Pengaruh Motivasi Terhadap Kinerja Karyawan}

Dari hasil pengujian, variabel motivasi berpengaruh positif dan signifikan terhadap kinerja karyawan Brownies Amanda Cabang Balikpapan. Hal ini terbukti dengan nilai $t_{\text {hitung }}>t_{\text {tabel }}$ $(4,206>1,996)$ dan nilai sig $0,000<0,05$. Artinya variabel motivasi secara parsial mempunyai pengaruh yang signifikan terhadap kinerja karyawan Brownies Amanda Cabang Balikpapan. Hasil penelitian variabel motivasi ini sesuai dengan penelitian sebelumnya yang dilakukan oleh Iga Mawarni Marpaung, Djamhur Hamid, dan Mohammad Iqbal (2014). yang menyatakan bahwa variabel motivasi mempunyai pengaruh positif dan signifikan terhadap kinerja karyawan.

Hal ini merupakan hasil suatu pemikiran yang tertuang dalam perencanaan atau program yang terpadu dan disesuaikan dengan situasi dan kondisi sesuai dengan keadaan eksternal ataupun internal.

\section{Pengaruh Gaya Kepemimpinan Terhadap Kinerja Karyawan}

Dari hasil pengujian, variabel gaya kepemimpinan berpengaruh positif dan signifikan terhadap kinerja karyawan Brownies Amanda Cabang Balikpapan. Hal ini terbukti dengan nilai $t_{\text {hitung }}(6,794)>t_{\text {tabel }}(1,996)$ dan nilai sig $0,000<0,05$. Dan hasil penelitian ini sesuai dengan penelitian sebelumnya yang dilakukan oleh Luis Aparicio Guterres, Wayan Gede Supartha (2016) menunjukkan bahwa gaya kepemimpinan berpengaruh positif dan signifikan terhadap kinerja karyawan.

Kepemimpinan merupakan suatu proses yang mempengaruhi dalam menentukan suatu tujuan pada organisasi, serta memotivasi perilaku dalam kinerja karyawan untuk dapat mencapai suatu tujuan. Dengan adanya gaya kepemimpinan yang tegas dan mampu mengarahkan bawahannya maka akan menghasilkan suatu kinerja yang lebih baik dari yang diharapkan.

\section{PENUTUP}

\section{Kesimpulan}

Hasil pengujian hipotesis secara simultan (uji F) menunjukkan bahwa ada pengaruh secara signifikan antara disiplin kerja $\left(\mathrm{X}_{1}\right)$, motivasi, $\left(\mathrm{X}_{2}\right)$, dan 
1. Gaya kepemimpinan $\left(\mathrm{X}_{3}\right)$ secara simultan (bersama-sama) terhadap kinerja karyawan Brownies Amanda Cabang Balikpapan yang dibuktikan dengan nilai $\mathrm{F}_{\text {hitung }}>\mathrm{F}_{\text {tabel }}$ atau 272,249 > 2,741, berada di daerah penolakan Ho. Sehingga hipotesis terdapat hubungan antara variabel disiplin kerja, motivasi dan gaya kepemimpinan dengan kinerja karyawan Brownies Amanda Cabang Balikpapan diterima.

2. Secara parsial disiplin kerja, motivasi dan gaya kepemimpinan memiliki pengaruh signifikan terhadap kinerja karyawan Brownies Amanda Cabang Balikpapan :

a. Pengaruh disiplin kerja dengan kinerja karyawan, ternyata diketahui tidak berpengaruh secara parsial (signifikan) terhadap kinerja karyawan Brownies Amanda Cabang Balikpapan.

b. Pengaruh motivasi dengan kinerja karyawan, ternyata diketahui ada pengaruh secara parsial (signifikan) terhadap kinerja karyawan Brownies Amanda Cabang Balikpapan..

c. Pengaruh gaya kepemimpinan dengan kinerja karyawan, ternyata diketahui ada pengaruh secara parsial (signifikan) terhadap kinerja karyawan Brownies Amanda Cabang Balikpapan.

\section{Saran}

Saran yang diberikan kepada Brownies Amanda Cabang Balikpapan terhadap kinerja karyawan yang menjadi objek penelitian:

1. Berdasarkan hasil penelitian diketahui variabel motivasi dan gaya kepemimpinan memberikan pengaruh signifikan terhadap kinerja karyawan Brownies Amanda. Oleh karena itu, pimpinan perlu mempertahankan untuk memotivasi karyawan dan dapat memperbaiki hasil kinerja yang lebih baik. Dengan meningkatkan jaminan kesejahteraan karyawan, rasa nyaman baik dari suasana lingkungan kerja dan hubungan antar karyawan dalam memotivasi diri mereka sendiri untuk bekerja sebaik-baiknya dan juga pimpinan lebih memberikan dorongan, semangat dan arahan bagi para karyawan Brownies Amanda Cabang Balikpapan. Selain itu, berkaitan dengan gaya kepemimpinan, pimpinan menjadi hal yang terpenting dalam suatu perusahaan. Sikap tegas dan mampu mendorong bawahannya dalam hal pekerjaan sangat penting demi terlaksananya tujuan perusahaan. Contohnya pimpinan harus mampu memberikan 
motivasi kepada karyawan Brownies Amanda Cabang Balikpapan, dan mampu menengahi serta memberikan solusi apabila terdapat masalah agar tidak terpecahpecah.

2. Bagi Brownies Amanda Cabang Balikpapan terhadap karyawannya perlu memperhatikan dan meningkatkan disiplin kerja, baik disiplin dalam hal waktu masuk dan pulang kerja, izin tanpa keterangan, maupun hal penyelesaian pekerjaan sehingga akan berdampak pada kinerja untuk mencapai tujuan bersama dengan memberikan teguran dan sanksi yang tegas kepada karyawan Brownies Amanda Cabang Balikpapan yang melakukan tindakan indicipliner. Hal ini menjadi sangat penting karena kedisiplinan merupakan hal yang harus dimiliki setiap karyawan dengan tingginya tingkat kedisiplinan akan mencerminkan bagaimana citra perusahaan dan karyawan itu sendiri. Dengan hasil variabel disiplin kerja yang tidak berpengaruh terhadap kinerja maka hal ini dapat menjadi acuan bagi perusahaan untuk lebih meningkatkan disiplin terhadap karyawannya.

\section{DAFTAR PUSTAKA}

Damayanti, Kristya. 2014. Pengaruh Motivasi, Disiplin Dan Stres Kerja terhadap Kinerja Pegawai Puskesmas di Kecamatan Ponggok Kabupaten Blitar. Jurnal Kompilek. Jurnal. Vol 6. No 1

Fahmi, Irham. 2016. Perilaku Organisasi Teori, Aplikasi, dan Kasus. Bandung: Alfabeta.

Ghozali, Imam. 2013. Aplikasi Analisis Multivariate dengan Program IBM SPSS 21. Semarang: Badan Penerbit Universitas Diponegoro.

Guterres, Luis Aparicio dan Wayan Gede Supartha. 2016. Pengaruh Gaya Kepemimpinan, dan Motivasi Kerja Terhadap Kinerja Guru. E-jurnal Ekonomi dan Bisnis Universitas Udayana. Jurnal. Vol. 5. No. 3

Irmayanti. 2014. Pengaruh Pelatihan, Motivasi, Stres Dan Kepuasan Kerja Terhadap kinerja Karyawan Bagian IT Helpdesk PT. ASTRAGRAPHIA TBK Cabang Balikpapan Area TOTAL E\&P INDONESIA. Skripsi. Sekolah Tinggi Ilmu Ekonomi MADANI Balikpapan (STIE MADANI). Balikpapan.

Mangkunegara, A.A. Prabu. 2013, Manajemen Sumber Daya Manusia Perusahaan, Cetakan kesebelas, Remaja Rosdakarya, Bandung.

Kinerja SDM. Cetakan Kesatu. Bandung: Refika Aditama.

Marpaung, Iga Mawarni, Djamhur Hamid dan Mohammad Iqbal. 2014. Pengaruh Motivasi Dan Disiplin Kerja Terhadap Kinerja Karyawan (Studi Pada Karyawan Rumah Sakit Reksa Waluya Mojokerto). Jurnal Administrasi Bisnis (JAB). Jurnal. Vol. 15. No. 2 Prahatsiwi, Cinintia Dyah. 2016. Pengaruh Kompensasi, Disiplin Kerja, Kepuasan Kerja, Dan Analisis Pekerjaan Terhadap kinerja Karyawan Pada PT. Sendang Sumber Kencana 
Balikpapan. Skripsi. Sekolah Tinggi Ilmu Ekonomi MADANI Balikpapan (STIE MADANI). Balikpapan.

Priyatno, Duwi. 2014. SPSS 22: Pengolahan Data Terpraktis. Edisi 1. Yogyakarta: C.V ANDI. Rivai, Veithzal \& Deddy Mulyadi. 2012. Kepemimpinan dan Perilaku Organisasi. Raja Grafindo Persada, Jakarta.

Rivai, Veithzal \& Sagala, E.J. 2010. Manajemen Sumber Daya Manusia Untuk Perusahaan. Jakarta: Raja Grafindo Persada.

Sajangbati, Ivonne, A. S.. 2013. Motivasi, Disiplin, dan Kepuasan Pengaruhnya Terhadap Kinerja Pegawai PT. POS INDONESIA (Persero) Cabang Bitung . Jurnal EMBA. Jurnal. 1(4): 669.

Sedarmayanti. 2016. Manajemen Sumber Daya Manusia Reformasi Birokrasi dan Manajemen Pegawai Negeri Sipil Edisi Revisi. Bandung: Refika Aditama.

Siagian, Sondang P. 2012. Teori Motivasi dan Aplikasinya. Cetakan Ketiga. Jakarta: Rineka Cipta.

Simamora, Henry. 1997. Manajemen Sumber Daya Manusia. Yogyakarta: STIE YKPN.

Sondole, E. M.R, Nelwan O.S, Palandeng I.D. 2015. Pengaruh Disiplin Kerja, Motivasi Dan Pengawasan Terhadap Kinerja Karyawan Pada PT. PERTAMINA (PERSERO) Unit Pemasaran VII, Terminal BBM Bitung. Jurnal EMBA. Jurnal. Vol. 3. No. 3

Sugiyono. 2009. Metode Penelitian Bisnis. Penerbit Alfabeta CV. Bandung. . 2009. Metode Penelitian Kuantitatif Kualitatif Dan R\&D. Penerbit Alfabeta CV. Bandung. . 2013. Metode Penelitian Bisnis. Penerbit Alfabeta CV. Bandung. . 2015. Metode Penelitian Kuantitatif Kualitatif Dan R\&D. Cetakan Kedua Puluh Dua. Penerbit Alfabeta CV. Bandung.

Sunyoto, Danang. 2012. Teori, Kuesioner, dan Analisis Data Sumber Daya Manusia (Praktik Penelitian). Yogyakarta: CAPS.

Umar, Husein. 2013. Metode Penelitian Untuk Skripsi Dan Tesis Bisnis. Jakarta: Raja Grafindo Persada

Wibowo. 2014. Manajemen Kinerja. Cetakan keempat. Jakarta: Rajawali Pers. . 2013. Perilaku Dalam Organisasi. Cetakan Kesatu. Jakarta: Rajawali Pers.

Wirawan, Fajar dan Edy Rahardja. 2015. Pengaruh Gaya Kepemimpinan Dan Motivasi Kerja Terhadap Kinerja Karyawan (Studi Pada PT. Warna Alam Indonesia). DIPONEGORO JOURNAL OF MANAGEMENT. Jurnal. Vol. 4. No. 2 